\title{
ELECTRICITY GENERATION IN MEDIATORLESS MICROBIAL FUEL CELL USING AGROBACTERIUM TUMEFACIENS SU-11 HAVING LACTOSE AND DAIRY WASTE AS CARBON SOURCE
}

\author{
Antony V Samrot*, Ponnaiah Paulraj, Iyappan Petchi \\ Department of Biomedical Sciences, Faculty of Medicine and Biomedical Sciences, \\ MAHSA University, Jenjarom, Selangor - 42610, Malaysia \\ Anupama S K, Mittapalli Nagesh, Raji P, Jenifer Selvarani A \\ Department of Biotechnology, Sathyabama Institute of Science and Technology, \\ Jeppiar Nagar, Chennai, Tamil Nadu, India

\section{Senthilkumar P} \\ Department of Chemical Engineering, Sathyabama Institute of Science and Technology, \\ Jeppiar Nagar, Chennai, Tamil Nadu, India
}

\section{Kasirajan Kasipandian}

Department of Electrical and Electronics Engineering, Faculty of Engineering and IT, MAHSA University, Jenjarom, Selangor - 42610, Malaysia

\section{Thirumurugan $\mathbf{R}$}

Department of Transfusion Medicine, JIPMER, Puducherry, India

*Corresponding Author Email id: antonysamrot@gmail.com

\begin{abstract}
Bioelectricity generation can be done in MFC. In this study, Agrobacterium tumefaciens SU-11 two electrodes with surface area of $2.376 \mathrm{~cm}^{2}$ and $69.5325 \mathrm{~cm}^{2}$ and two different length salt bridge were used for electricity generation in mediator less microbial fuel cell. Two different concentrations of lactose i.e. $2 \%$ and $3 \%$ lactose were used as carbon source. More electricity generation was found at $2 \%$ lactose and $2.376 \mathrm{~cm}^{2}$ electrode used MFC. The organism was able to produce around $450 \mathrm{mV}$ while dairy wastewater was used as carbon source.
\end{abstract}

Keywords: Electricity Generation, Microbial Fuel, Agrobacterium, Tumefaciens, Carbon Source. 
Cite this Article: Antony V Samrot, Anupama S K, Mittapalli Nagesh, Raji P, Senthilkumar P, Jenifer Selvarani A, Ponnaiah Paulraj, Kasirajan Kasipandian, Thirumurugan R, Iyappan Petchi, Electricity Generation in Mediatorless Microbial Fuel Cell Using Agrobacterium Tumefaciens SU-11 Having Lactose and Dairy Waste as Carbon Source, International Journal of Advanced Research in Engineering and Technology (IJARET), 10 (6), 2019, pp 89-95.

http://iaeme.com/Home/issue/IJARET?Volume $=10 \&$ Issue $=6$

\section{INTRODUCTION}

World energy demand is increasing day by day. Production of energy using the renewable feed stocks help in producing energy in sustainable manner and also reduce pollution. When the energy is derived out of wastewater it gives us two advantage as water can be recycled after treatment and also reduces the cost of water treatment [1]. MFC (microbial fuel cell) is a system where electrical energy is produced by biochemical reaction performed by microorganisms [2]. MFC can be used to produce energy from wastewater, thus this technology becomes revolution as two purposes are solved, one is wastewater treated and other is getting energy out of it [3]. Mohan et al [3] used mixed consortium and produced more bioelectricity. Using the mixed consortia act synergistically as the byproduct of one organism can be used by the next organism. Sometimes, it might be reason for less energy production as the other organism diverts the metabolism and no hydrogen is produced [3].

A microbial fuel cell (MFC) is consisting of anode and cathode chamber, where it is partitioned using a salt bridge or proton exchange membrane (PEM). Biochemical reaction of bacteria happens at anode and electrons generated in the reaction is transferred through a circuit to generate electricity, proton moves through the PEM to anode and forms water $[4,5]$. Park and Zeikus [6] incorporated dyes like neutral red and metals (such as $\mathrm{Mr}^{4+}, \mathrm{Fe}^{3+}$ ) to the graphite anodes and investigated. Wastewater treatment is possible with MFC $[7,8]$. In this work, microorganism was isolated from garden soil of Sathyabama Institute of Science and Technology, Chennai, Tamil Nadu - 600 119, India and utilized for electricity generation in MFC having lactose /dairy waste water in anode chamber and also to evaluate electrode surface area and the length of salt bridge for better electricity generation.

\section{MATERIALS AND METHOD}

\subsection{Isolation of Bacteria}

Soil sample was subjected for serial dilution and pour plate was performed on minimal media. After 2 days of incubation at $37^{\circ} \mathrm{C}$, pure culture obtained was inoculated into $50 \mathrm{ml}$ of the minimal media. The above procedures were repeated three times in order to stimulate an enrichment culture. After the enrichment steps, the culture broth was streaked on nutrient agar for storage.

\subsubsection{Isolation and identification of bacteria}

The organism was identified by its biochemical characteristics as well as by 16SrRNA sequencing.

\subsection{Microbial Fuel Cell Construction with Salt Bridge Set up and Bioelectricity Generation}

The "H" shaped microbial fuel cell consists of an anaerobic anode chamber and an aerobic cathode chamber. It was made using the autoclavable plastic bottles of capacity $500 \mathrm{~mL}$, which are being connected using salt bridge made of agar (saturated with $\mathrm{NaCl}$ ) (two lengths were used, they were $16.5 \mathrm{~cm}$ length and $11.5 \mathrm{~cm}$ length). Graphite rods acted as electrodes in 
both the chambers. Anaerobic condition in the anode chamber was maintained and the cathode chamber was being aerated using aerator pumps (Fig.1). Two electrodes with surface area of $2.376 \mathrm{~cm}^{2}$ and $69.5325 \mathrm{~cm}^{2}$ were used. Two different concentration of lactose was used in this study, i.e. $2 \%$ lactose and $3 \%$ lactose in the minimal media used by Samrot et al [9].

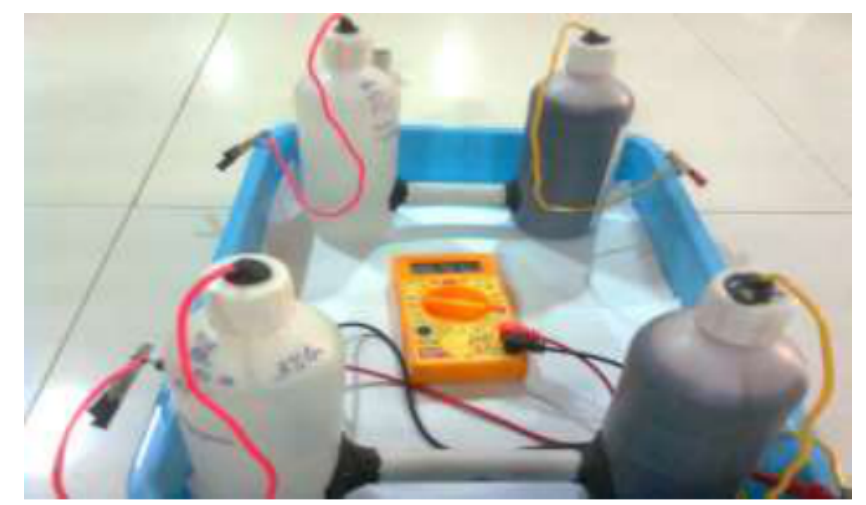

Figure 1 Microbial Fuel Cell Salt Bridge Set Up

\subsection{Electricity Generation from Dairy Wastewater}

\subsubsection{Collection of Sewage Sample}

Sewage sample was collected from Aavin, Sholinganallur, and Chennai. The sample was collected in a sterile glass container and brought to the lab and stored in $4^{0} \mathrm{C}$ till it used.

\subsubsection{Electricity Generation in MFC with Salt Bridge}

Collected dairy wastewater was sterilized by autoclaving and added into the anode chamber of salt bridge MFC with the electrode of size which yielded more electricity in this study was chosen. Potential difference in $\mathrm{mV}$ was noted for $400 \mathrm{~h}$ at regular time interval.

\subsubsection{Substrate Analysis}

BOD and COD estimation (open reflux method) was carried out with initial sample and final sample to determine the activity of microorganism. The detection of the carbohydrate was done by DNS method, Protein concentration was estimated using Lowry's method [12]. Estimation of minerals like chloride, fluoride, nitrate, iron, free chlorine and hardness of water were done using multi parameter water testing kit (HIMEDIA WT023).

\section{RESULTS AND DISCUSSION}

A pure culture of was isolated and it was being sequenced by 16SrRNA gene analysis, it was confirmed to be Agrobacterium tumefaciens (Genbank number: JQ756125).

Electricity generation by the microbe was analysed in salt bridge set up. The organism was found to produce constant potential difference in the range of $700 \mathrm{mV}$ to $750 \mathrm{mV}$ when it was incubated with $2 \%$ lactose in MFC with $16.5 \mathrm{~cm}$ long salt bridge. This was higher than the electricity produced by the organism in MFC with 11.5. Here the electrode size was kept constant as $2.376 \mathrm{~cm}^{2}$ (Fig.2). With the constant electrode surface area of $69.5325 \mathrm{~cm}^{2}$ and varied salt bridge length $(11.5$ and $16.5 \mathrm{~cm})$ did not have any impact on potential difference produced by the organism (Fig.3). With lactose 3\% and electrode surface area of $2.376 \mathrm{~cm}^{2}$, organism was found to generate constant potential difference in MFCs with varied length of salt bridge $(11.5 \mathrm{~cm}$ and $16.5 \mathrm{~cm})$ (Fig.4), but it was found to be fluctuating in electrode surface area of $69.5325 \mathrm{~cm}^{2}$ in both the salt bridges $(11.5 \mathrm{~cm}$ and $16.5 \mathrm{~cm})($ Fig. 5$)$. 
Antony V Samrot, Anupama S K, Mittapalli Nagesh, Raji P, Senthilkumar P, Jenifer Selvarani A, Ponnaiah Paulraj, Kasirajan Kasipandian, Thirumurugan R, Iyappan Petchi

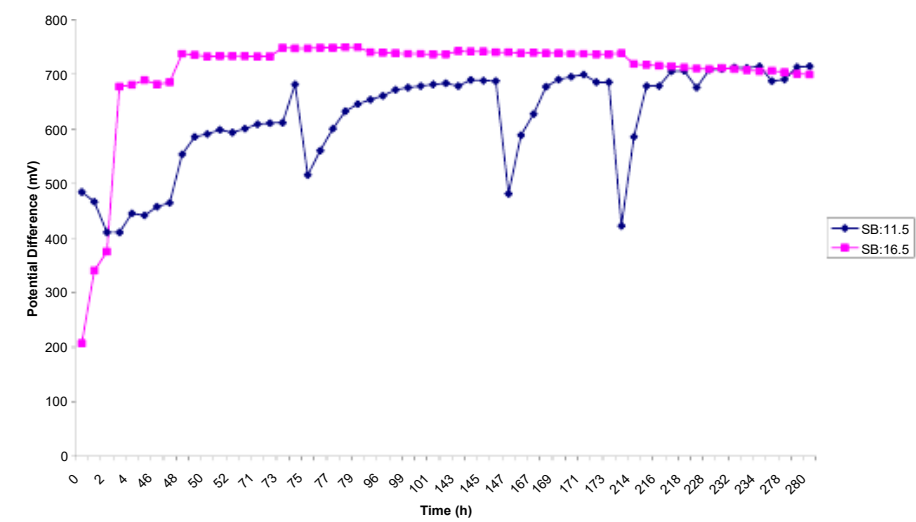

Figure 2 Electricity generation by A.tumefaciens in mediatorless MFC with $2 \%$ lactose (varying salt bridge length and constant electrode size of $2.376 \mathrm{~cm}^{2}$ )

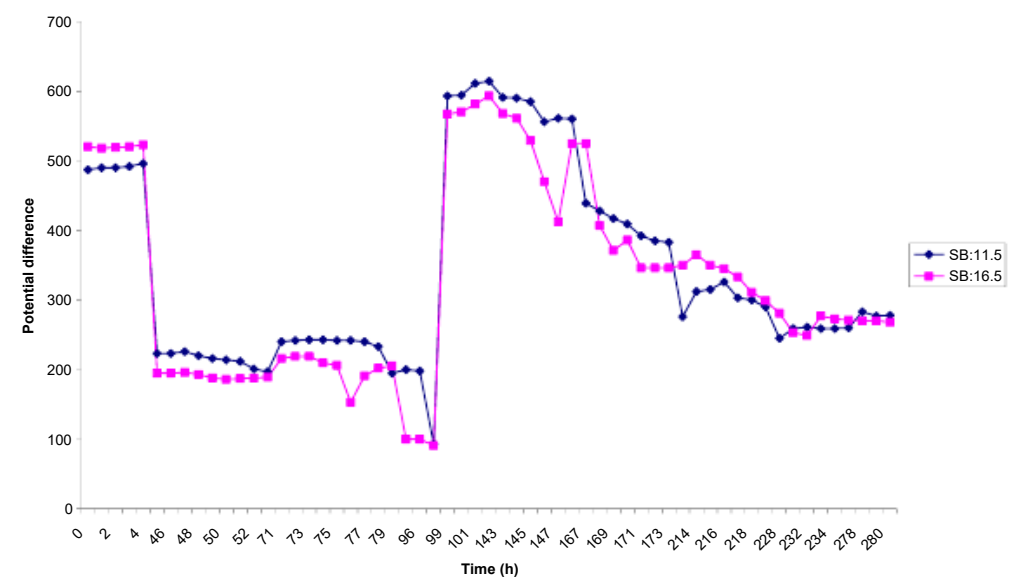

Figure 3 Electricity generation by A.tumefaciens in mediatorless MFC with $2 \%$ lactose (varying salt bridge length and constant electrode size of $69.5325 \mathrm{~cm}^{2}$ )

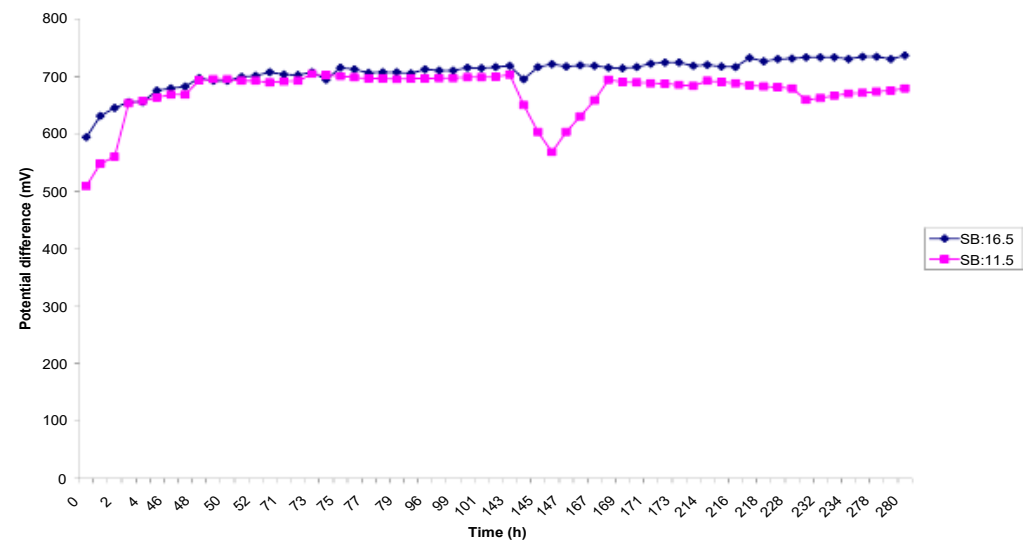

Figure 4 Electricity generation by A.tumefaciens in mediatorless MFC with 3\% lactose (varying salt bridge length and constant electrode size of $2.726 \mathrm{~cm}^{2}$ ) 
Electricity Generation in Mediatorless Microbial Fuel Cell Using Agrobacterium Tumefaciens SU-11 Having Lactose and Dairy Waste as Carbon Source

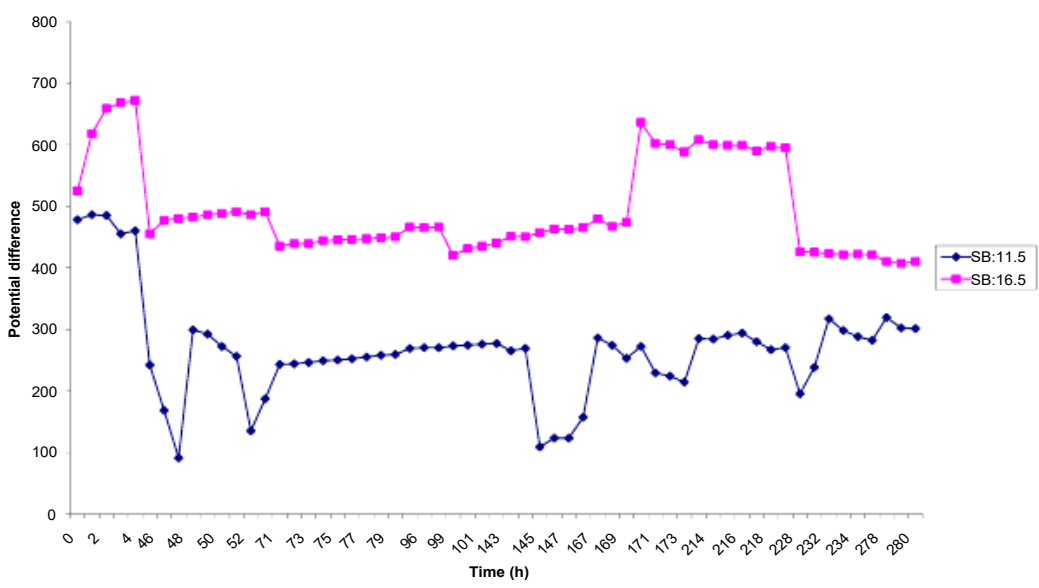

Figure 5 Electricity generation by A.tumefaciens in mediatorless MFC with $3 \%$ lactose (varying salt bridge length and constant electrode size of $69.5325 \mathrm{~cm}^{2}$ )

600

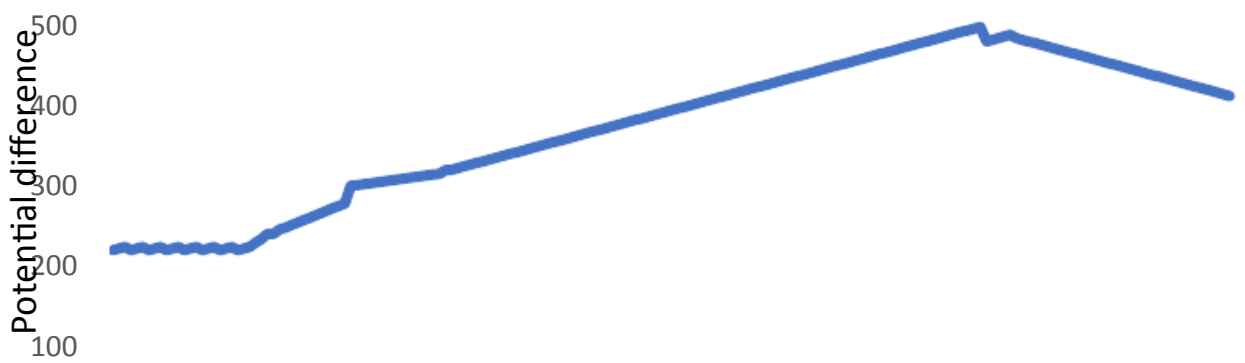

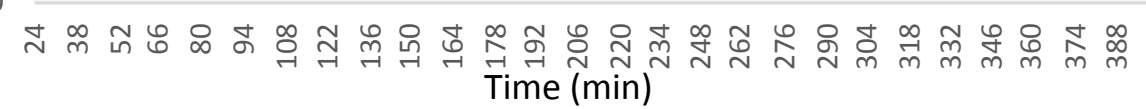

Table: 1 Analysis of Biochemical parameters of dairy waste

\begin{tabular}{|c|l|c|c|}
\hline \multirow{2}{*}{ SI No: } & \multirow{2}{*}{ Test } & \multicolumn{2}{c|}{ Values(mg/L) } \\
\cline { 3 - 4 } & & Before(0 hours) & After(400 hours) \\
\hline 1. & REDUCING SUGAR & 49.313 & 24.2 \\
\hline 2. & PROTEIN & 19.5090 & 90 \\
\hline 3. & BOD & 40 & 6.7977 \\
\hline 4. & COD & 40 & 0 \\
\hline 5. & CHLORIDE TEST & 0.5 & 30 \\
\hline 6. & FLOURIDE TEST & 10 & 9 \\
\hline 7. & NITRATE TEST & 0.3 & 0.3 \\
\hline 8. & IRON TEST & 0.0 & 0 \\
\hline 9. & RF CHLORINE TEST & 150 & 140 \\
\hline 10. & HARDNESS OF WATER & & 0 \\
\hline
\end{tabular}

Thus, electrode with surface area of $2.376 \mathrm{~cm}^{2}$ was chosen for the further study with treatment of dairy waste. In this study, the bacterium used was found to produce around 450 $\mathrm{mV}$, where Parkash et al [10] could produce $0.4 \mathrm{~V}$ using the dairy waste. The reducing sugar concentration was estimated for wastewater before and after the set up was run. It showed that the concentration of reducing sugar was reduced which showed that the microbes have utilized it for their survival. The COD and BOD of the sample was also estimated and the values were found to be reduced in the final sample compared to initial sample and the values are shown in Table 1. Sanjay et al [11] found that the treatment of dairy wastewater was found 
to be reducing the BOD and COD of the sample. Table 1 shows that the protein content of the sample was reduced after the set up was run, which means the microbes have utilized the protein for their growth and thus the protein amount was found to be reduced in the sample. Mineral analysis was done with the initial samples and final samples, but the difference was not much significant (Table 1).

\section{CONCLUSION}

Two electrodes with surface area of $2.376 \mathrm{~cm}^{2}$ and $69.5325 \mathrm{~cm}^{2}$ and two different length salt bridge were used to find the electricity generation in mediator less microbial fuel cell having lactose as carbon source. It was found that $2 \%$ lactose and $2.376 \mathrm{~cm}^{2}$ electrode utilized MFC gave maximum output. Even the organism used in this study was capable of producing electricity from dairy waste which was around $450 \mathrm{mV}$.

\section{AUTHOR'S CONTRIBUTION}

All the authors involved in idea creation and made intellectual contribution to the work. All the authors involved in manuscript preparation.

\section{ACKNOWLEDGEMENT}

None

\section{FUNDING}

No fund was received for this study.

\section{CONFLICT OF INTEREST}

The authors have no conflict of interest.

\section{DATA AVAIALABILITY}

N/A

\section{ETHICS STATEMENT}

No animals or humans are used in this study. Hence, the work does not require ethical clearance.

\section{REFERENCES}

[1] A.S. Mathuriya, and V.N. Sharma, Treatment of Brewery Wastewater and Production of Electricity through Microbial Fuel Cell Technology. International Journal of Biotechnology and Biochemistry, 6, 2010, 71-80.

[2] B.E., Logan, and J.M. Regan, Microbial fuel cells--challenges and applications. Environmental Science \& Technology, 1, 2006, 5172-5180.

[3] V.S. Mohan, S.V. Raghavulu, and P.N. Sarma, Biochemical evaluation of bioelectricity production process from anaerobic wastewater treatment in a single chambered microbial fuel cell (MFC) employing glass wool membrane. Biosensors and Bioelectronics, 23, 2008, 1326-1332.

[4] K. Rabaey, and W. Verstraete, Microbial fuel cells: novel biotechnology for energy generation. Trends in Biotechnology, 23, 2005, 291-8.

[5] S.P. Indumathi, R. Karthik, Angelin C Pushpam, M.C. Vanitha and K. Ramalingam. Dehydrogenases and Ascorbic Acid Profile with Microbial Analysis between Two Green 
Mussel (Perna Viridis) Populations. International Journal of Advanced Research in Engineering and Technology, 6(10), 2015, pp. 51-61.

[6] K. Rabaey, J. Rodríguez, L.L Blackall, J. Keller, P. Gross, D. Batstone, W. Verstraete, and K.H. Nealson, Microbial ecology meets electrochemistry: electricity driven and driving communities. The ISME Journal, 1, 2007, 9-18.

[7] D.H. Park, and J.G. Zeikus, Improved fuel cell and electrode designs for producing electricity from microbial degradation. Biotechnology and Bioengineering, 81(3), 2003, 348-55.

[8] Ganjar Samudro, Syafrudin, Irawan Wisnu Wardana, Harida Samudro and Sarwoko Mangkoedihardjo, Determination of the Specific Energy of Mixed Waste Decomposition in Compost Solid Phase Microbial Fuel Cells (CSMFCS), International Journal of Civil Engineering and Technology, 9(11), 2018, pp. 1316-1324.

[9] C.M. Drisya, and N.T. Manjunath, Dairy Wastewater Treatment and Electricity Generation Using Microbial Fuel Cell. International Research Journal of Engineering and Technology, 4(8), 2017, 1293 - 1296.

[10] N.S.N. Hisham, S.D. Zain, S. Jusoh, N. Anuar, F. Suja, A. Ismail, N.E.A. Basri, Microbial fuel cells using different types of wastewater for electricity generation and simultaneously removed pollutant. Journal of Engineering Science and Technology, 8(3), 2013, 316 - 325.

[11] A.V. Samrot, A. Reddy, S. Sukeetha, P. Senthilkumar, Accumulation of Poly [(R)-3Hydroxyalkanoates] in Enterobacter cloacae SU-1 during growth with two different carbon sources in batch culture. Applied Biochemistry and Biotechnology, 163(1), 2011, 195-203.

[12] Chonde Sonal G, Mishra A. S and Raut P. D, Bioelectricity Production From Wastewater Using Microbial Fuel Cell (Mfc), International Journal of Advanced Research in Engineering and Technology (IJARET), Volume 4, Issue 6, September - October 2013, pp. 62-69

[13] Rajesh Kanna, Biological Surfactant Production by Pseudomonas Aeruginosa ATCC 9027 and Probable Application in Microbial Enhanced Oil Recovery (MEOR). International Journal of Civil Engineering and Technology, 8(10), 2017, pp. 619-626.

[14] A. Parkash, S. Aziz, I. Nazir, S.A. Soomro, Utilizing dairy wastewater for electricity generation using environment friendly double chambered microbial fuel cell. Nust Journal of Engineering Sciences, 8(1), 2015, 44- 50.

[15] T. Opoku-Donkor, R. Y. Tamakloe, R. K. Nkum and K. Singh, Effect Of Cod on Ocv, Power Production and Coulombic Efficiency of Single-Chambered Microbial Fuel Cells

, International Journal of Advanced Research in Engineering and Technology (IJARET), Volume 4, Issue 7, November - December 2013, pp. 198-206

[16] R. Y. Tamakloe, M. Commey, Agoe Obed Nai, Turkson Samuel Kwamena and K. Singh, Effect of Porosity on Ocv and Wastewater Treatment Efficiency of A Clay Partitioned Ion-Exchange Double-Chamber Microbial Fuel Cell, International Journal of Advanced Research in Engineering and Technology (IJARET), Volume 6, Issue 6, June (2015), Pp. 06-11

[17] S. Sanjay, D. Sowmyashree, T.H. Udayashankara, Treatment of dairy wastewater and bioelectricity generation using membraneless microbial fuel cell. International Journal of Civil Engineering and Technology, 9(5), 2018, 679-685.

[18] O.H. Lowry, N.J. Rosebrough, A.L. Fair, R.J. Randall, Protein Measurement with the Folin Phenol Reagent. The Journal of Biological Chemistry, 193, 1951, 265-275. 